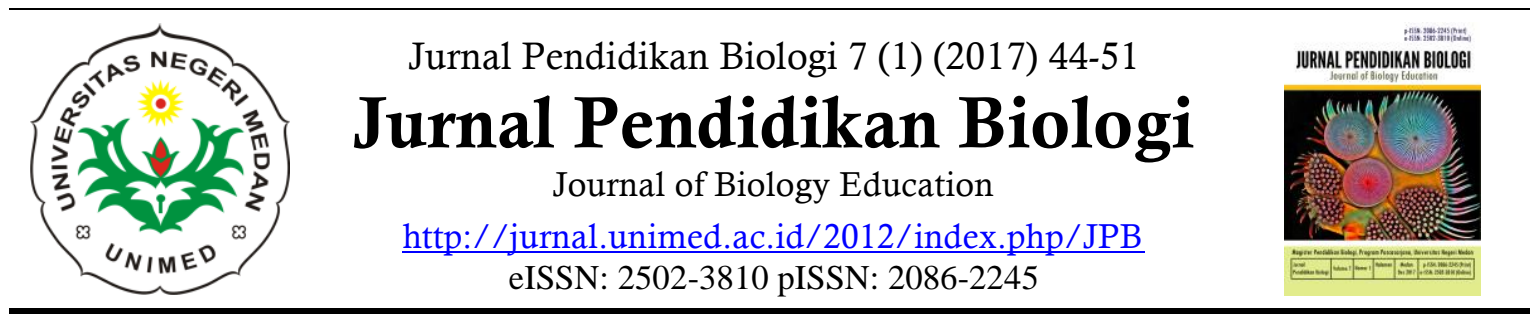

\title{
Analisis Partisipasi Siswa dalam Menjaga Kesehatan Lingkungan Ditinjau Melalui Kecerdasan Naturalis
}

\author{
Wisnu Surya Pratama ${ }^{1}$, Rita Istiana ${ }^{2 *}$, Nandang Hidayat $^{2}$ \\ ${ }^{1}$ Mahasiswa Program Studi Pendidikan Biologi, FKIP, Universitas Pakuan \\ ${ }^{2}$ Dosen Program Studi Pendidikan Biologi, FKIP, Universitas Pakuan \\ *Korespondensi: rita istiana@unpak.ac.id
}

\begin{abstract}
This study was a mixed method sequential explanatory research. This study aimed to obtain information of a relationship between naturalist intelligence and students' participation in maintaining environmental health and the other factors which influence it. This study was conducted from February to October 2017. The analysis unit was 169 students of one of public junior high school in South Bogor District. Quantitative research results showed that correlation coefficient (ry) between naturalist intelligence and students' participation in maintaining environmental health was 0,407 . This value showed that naturalist intelligence have quite a high contribution to students' participation in maintaining environmental health. Qualitative research results showed that there are the other factors which can influence students' participation in maintaining environmental health, such as social interaction with their friends in the home or school environment, students' understanding of important functions of living things, students' habit and self-awareness, and guidance from both parents and teachers.
\end{abstract}

Keywords: Environmental health, intelligence, naturalist intelligence, participation

\section{PENDAHULUAN}

Selama beberapa dekade, sistem tata kelola lingkungan global telah memperhatikan bahan kimia berbahaya dan polutan serta pengelolaan dan dampaknya terhadap kesehatan dan lingkungan. Sistem peraturan internasional untuk bahan kimia, limbah dan mekanisme yang melaluinya mengatur produksi, penggunaan, dan perdagangan bahan kimia di seluruh dunia (Peraturan Menteri Perdagangan RI, 2014). Hasil penelitian Escobar (2018) menyimpulkan sasaran pembangunan berkelanjutan (SDGs) baru menangani bahan kimia dan dampaknya terhadap kesehatan dan lingkungan.
Pentingnya lingkungan yang baik dan bersih adalah bagian dari kebutuhan manusia untuk kesehatan. Timbulnya berbagai penyakit di masyarakat yang berjangkit secara epidemi, yang sebetulnya hal ini dapat dicegah kalau kesehatan lingkungan cukup baik. Manajemen keselamatan dan kesehatan masyarakat adalah kekhawatiran yang menimbulkan tantangan di seluruh dunia. Dalam konvensi Rio membahas isu pengadaan air bersih untuk rakyat miskin atau water for life yang salah satu tema yang diusung untuk meningkatkan kesadaran dan kepedulian masyarakat untuk memanfaatkan air secara bijak. Penelitian yang dilakukan oleh Baguma (2016) menyimpulkan bahwa peningkatan kebijakan untuk memperbaiki 
administrasi layanan kesehatan, memperkuat implementasi Konvensi Rio mengenai masalah lingkungan, pengendalian bahaya lingkungan dan kesehatan masyarakat.

Kualitas lingkungan pada masa yang akan datang sangat bergantung pada generasi yang berkualitas, peduli lingkungan serta mampu mewujudkan kepeduliannya dalam kehidupan sehari-hari (Chandra, 2006). Lingkungan hunian yang sehat, terutama bagi orang dewasa yang lebih tua, telah muncul sebagai isu penting dalam agenda politik dan perencanaan di China. Kualitas perumahan dan lingkungan yang baik dan lingkungan sosial yang aman berkontribusi terhadap kondisi kesehatan subjektif, fisik dan mental orang dewasa yang lebih baik (Can, 2017). Sikap dan kelakuan ramah kesehatan lingkungan masyarakat yang tidak tumbuh disebabkan oleh berbagai macam faktor, seperti ekonomi, kebudayaan, dan penegakan hukum yang kurang baik. Pendekatan penelitian dan pengembangan kebijakan tentang kesehatan manusia sebagai satu di antara sejumlah kapasitas yang muncul dari interaksi manusia dengan dunia sosial dan alam (Fox, 2016). Hasil penelitian tersebut menjelaskan fokus intervensi dan pergeseran kebijakan untuk mendorong interaksi sosial dan alam yang dapat meningkatkan potensi lingkungan. Hal ini juga akibat rendahnya partisipasi siswa sebagai anggota dari masyarakat dalam menjaga kesehatan lingkungan, yang menyebabkan kesehatan lingkungan terabaikan.

Kesadaran terhadap lingkungan merupakan bentuk kepedulian seseorang terhadap kualitas lingkungan (Darmawan, 2010). Hasil penelitian yang dilakukan oleh Yossinia (2017) bahwa sikap, pengetahuan dan tindakan siswa dalam menjaga kebersihan lingkungan sekolah di Padang sangat rendah.
Partisipasi siswa dalam menjaga kesehatan lingkungan dapat ditumbuhkan melalui pendidikan formal maupun non formal yaitu dengan cara memberikan pengetahuan, pemahaman dan cara pengaplikasian kesehatan lingkungan dalam kehidupan sehari-hari (Pradono, 2014). Siswa yang memiliki pengetahuan yang cukup tentang kesehatan dan lingkungan dapat mempengaruhi partisipasi seseorang dalam menjaga kesehatan lingkungan. Selain itu apabila pengetahuan tersebut ditunjang dengan kecerdasan naturalis yang merupakan keahlian mengenali kepekaan pada fenomena alam di lingkungan sekitar maka siswa akan lebih peduli dengan kesehatan lingkungan (Chandra, 2006). Nobuo (2017) mengatakan bahwa kecerdasan naturalis yang dimiliki oleh individu berinteraksi berkebutuhan khusus mampu memiliki bakat untuk merawat, menjinakkan, atau secara halus dengan berbagai makhluk hidup. Kecerdasan naturalis menurut Juniar (2015) pada intinya berkaitan dengan isi alam, yaitu baik flora maupun fauna. Hal ini sejalan dengan pemikiran Gardner (2009) yang mengatakan bahwa kecerdasan naturalis adalah keahlian dalam mengenali dan mengklasifikasikan berbagai spesies flora dan fauna, serta kemampuan dalam melakukan kategorisasi dan membuat hierarki terhadap keadaan organisme seperti tumbuh-tumbuhan, binatang dan alam. Armstrong (2009) berpendapat bahwa siswa yang memiliki kecerdasan naturalis mempunyai ciri ciri sebagai berikut: berbicara tentang binatang peliharaan atau favorit, atau tempat yang disukai di alam ketika di dalam kelas, menyukai pergi ke alam seperti kebun binatang, menunjukan sensitivitas terhadap informasi tentang alam, memelihara tanaman di dalam kelas, memelihara kandang hewan peliharan dan akuarium di 
kelas, senang ketika belajar tentang ekologi, alam, tumbuhan dan binatang.

Berdasarkan hasil observasi awal pada Siswa kelas VIII SMP Se Kecamatan Bogor Selatan diperoleh bahwa $65 \%$ siswa tidak ikut serta dalam bergotong royong membersihkan selokan di tempat tinggalnya, 55\% siswa tidak membersihkan bak mandi secara rutin, dan $55 \%$ siswa enggan mengikuti seminar tentang lingkungan. Data tersebut menunjukan bahwa tingkat partisipasi siswa dalam menjaga kesehatan lingkungan masih tergolong cukup rendah seperti kurangnya partisipasi siswa dalam aspek memelihara lingkungan tempat tinggal siswa, serta pengembangan daya pikir siswa dalam mewujudkan lingkungan yang sehat. Hal ini perlu disikapi dengan bijak oleh pendidik di sekolah masing-masing. Siswa perlu diberikan pembinaan dengan cara memberikan pengetahuan dan pemahaman tentang kesehatan lingkungan, serta menanamkan kecerdasan naturalis terhadap siswa dalam upaya menjaga kesehatan lingkungan. Berdasarkan uraian di atas maka masalah dalam penelitian ini yaitu adakah hubungan antara kecerdasan naturalis dengan partisipasi siswa dalam menjaga kesehatan lingkungan dan apa saja faktor lain selain variabel tersebut yang ikut berperan dalam meningkatkan partisipasi siswa dalam menjaga kesehatan lingkungan.

\section{METODE PENELITIAN}

Tujuan penelitian ini adalah untuk mengetahui hubungan antara kecerdasan naturalis dengan partisipasi siswa dalam menjaga kesehatan lingkungan. Penelitian ini dilakukan di SMP Negeri di Kecamatan Bogor Selatan. Waktu penelitian dimulai dari bulan Februari sampai dengan Oktober 2017. Subjek dalam penelitian ini adalah peserta didik kelas VIII di SMP Negeri di
Kecamatan Bogor Selatan tahun ajaran 2016/2017. Penentuan sampel penelitian dilakukan dengancara teknik multistage random sampling. Sampel penelitian sebanyak 169 responden. Variabel penelitian ini adalah Pertisipasi siswa dalam menjaga kesehatan lingkungan sebagai variabel terikat dan kecerdasan naturalis sebagai variabel bebas. Instrument yang digunakan dalam penelitian ini adalah instrument test untuk mengukur kecerdasan naturalis dan instrument non test/ angket untuk mengukur partisipasi siswa dalam menjaga kesehatan lingkungan. Metode yang digunakan dalam penelitian ini adalah sequental explanatory. Metode penelitian sequential explanatory adalah metode penelitian yang menggabungkan antara metode kuantitatif dan kualitatif secara berurutan dimana pada tahap pertama penelitian dilakukan dengan menggunakan metode kuantitatif dan pada tahap kedua menggunakan metode kualitatif (Sugiyono, 2016). Metode kuantitatif berperan untuk memperoleh data yang terukur dan metode kualitatif berperan untuk memperdalam data kuantitatif. Data dan informasi kualitatif tersebut diperoleh berdasarkan hasil wawancara, observasi dan dokumentasi. Data kualitatif diperoleh dari reduksi data, data display, dan conclution drawing.

\section{HASIL DAN PEMBAHASAN}

\section{Hasil Penelitian Kuantitatif}

Deskripsi data hasil penelitian dikelompokan menjadi dua variabel yang terdiri atas data variabel terikat yaitu Partisipasi Siswa dalam Menjaga Kesehatan Lingkungan dan data variabel bebas yaitu Kecerdasan Naturalis. Jumlah sumber data sebanyak 169 responden yang terdiri atas 97 siswa kelas VIII SMP Negeri 9 Kota Bogor dan 72 siswa kelas VIII SMP 
Negeri 13 Kota Bogor. Berdasarkan Tabel 1 dibawah ini, perhitungan keberartian regresi diperoleh Fhitung sebesar 33,12 > Ftabel 3,90 dengan menggunakan taraf signifikan $\alpha=0,05$. Maka dapat disimpulkan bahwa persamaan regresi signifikan.

Tabel 1. Uji Linieritas Regresi

\begin{tabular}{lllllll}
\hline Sumber variasi & $\mathbf{d k}$ & $\mathbf{J K}$ & $\mathbf{K T}$ & $\mathbf{F}_{\text {hitung }}$ & $\mathbf{F}_{\text {tabel }}$ & Ket \\
\hline Total & 169 & 2719800 & 2719800 & & & \\
Koef (a) & 1 & 2697679,91 & 2697679,91 & & & \\
Regresi (b/a) & 1 & 3660,66 & 3660,66 & 33,12 & 3,90 & Signifikan \\
Sisa & 167 & 18459,43 & 110,54 & & & \\
Tuna Cocok & 32 & 1227,40 & 38,36 & 0,30 & 1,53 & Linier \\
Galat & 137 & 17232,03 & 125,78 & & & \\
\hline
\end{tabular}

Keterangan: $\mathrm{dk}=$ derajat kebebasan, $\mathrm{JK}=$ jumlah kuadrat, $\mathrm{KT}=$ kuadrat total

\section{Uji Regresi Linier Sederhana}

Berdasarkan perhitungan statistika diperoleh persamaan regresi $\hat{\mathrm{Y}}=$ 54,632+0,547X. Hasil regresi linier sederhana terhadap data penelitian diperoleh arah regresi sebesar $0,547 \mathrm{X}$ pada arah yang sama dengan konstanta sebesar 54,632. Selanjutnya dari persamaan regresi tersebut dapat diinterpretasikan bahwa sebelumsiswa memperoleh kecerdasan naturalistelah memiliki partisipasi siswa dalam menjagakesehatan lingkungan secara konstanta 54,632. Setiap kenaikan satu unit nilai kecerdasan naturalis akan menyebabkan pertambahan partisipasi siswa dalam menjaga kesehatan lingkungan sebesar 0,547 .

\section{Uji Hipotesis}

Berdasarkan perhitungan uji korelasi didapat koefisien korelasi sebesar 0,407 artinya terdapat hubungan positif antara kecerdasan naturalis $(\mathrm{X})$ dengan partisipasi siswa dalam menjaga kesehatan lingkungan (Y). Hubungan positif ini dinilai cukup tinggi. Kemudian koefisien determinasi (ry2) berada pada angka 0,166 yang menunjukan bahwa 16,6\% partisipasi siswa dalam menjaga kesehatan lingkungan dipengaruhi oleh adanya variabel kecerdasan naturalis, sedangkan sisanya merupakan faktor-faktor lain yang turut berperan dalam pembentukan partisipasi dalam menjaga kesehatan lingkungan.

Kecerdasan naturalis terhadap partisipasi siswa dalam menjaga kesehatan lingkungan memiliki hubungan yang positif. Hal ini sejalan dengan penelitian yang dilakukan Anna (2016) bahwa sikap kepedulian siswa terhadap lingkungan juga dapat dipengaruhi oleh kecerdasan naturalis. Siswa dapat menunjukan kemampuannya dalam memahami alam dan lingkungan sekitarnya dan menunjukan kepekaannya terhadap keadaan sekolah seperti merawat tanaman hias di sekolah serta menanam kembali atau mengganti tanaman di sekolah yang mati. Menurut penelitian Husin (2012), terdapat interaksi antara kecerdasan naturalis dalam meningkatkan konsep ekosistem, karena jika seseorang memiliki kecerdasan naturalis maka orang tersebut dapat mengendalikan alam dengan baik tanpa harus terjadi kerusakan pada alam tersebut.

Hal ini senada dengan pendapat Yaumi (2012) tentang ciri-ciri siswa yang memiliki kecerdasan naturalis seperti kesenangan terhadap alam, peduli terhadap binatang dan tumbuhan serta mampu mengolah dan melestarikan alam. Sejalan dengan pendapat di atas, maka Sujiono 
(2009) menyatakan bahwa kecerdasan naturalis sangat dibutuhkan setiap orang sejak mereka berusia dini, terlebih lagi pada usia lima tahun pertama. Sebab kecerdasan ini mampu menjaga serta memelihara nalurinya untuk hidup nyaman di alam bebas bersama makhluk-makhluk ciptaan Tuhan yang lain (Rashidiyanti, 2016).

\section{Hasil Penelitian Kualitatif}

Data kualitatif diperoleh berdasarkan hasil wawancara, observasi dan dokumentasi. Data kualitatif kemudian dianalisis dengan reduksi data, data display, dan conclution drawing. Hasil penelitian kualitatif diperoleh melalui wawancara terhadap siswa, kepala sekolah, guru dan orang tua siswa. Analisis data tersebut meliputi kegiatan reduksi data, penyajian data dan penarikan kesimpulan. Penelitian kualitatif dilakukan setelah didapatkan hasil dari penelitian kuantitatif. Penyusunan sub fokus pada penelitian ini disesuaikan dengan hasil penelitian kuantitatif yang sudah diperoleh sebelumnya yaitu adakah faktor lain selain variabel kecerdasan naturalis yang mempengaruhi partisipasi siswa dalam menjaga kesehatan lingkungan.

Berdasarkan data yang diperoleh, maka data tersebut diuraikan dalam bentuk hasil reduksi data. Berikut ini hasil dari reduksi data yang telah dilakukan untuk mengetahui faktor yang membuat cukup tingginya partisipasi siswa dalam menjaga kesehatan lingkungan yang ditinjau dari kecerdasan naturalis: kebiasaan siswa dalam merawat tanaman di kelasnya masing-masing, menyukai materi pembelajaran tentang alam seperti hewan dan tumbuhan beserta habitatnya, berantusias dalam mengikuti kegiatan study tour atau belajar di alam bebas, sarana yang mendukung (program sekolah) untuk mendukung menjaga kesehatan lingkungan.
Berikut ini hasil dari reduksi data yang telah dilakukan untuk mengetahui faktor lain yang mempengaruhi partisipasi siswa dalam menjaga kesehatan lingkungan selain kecerdasan naturalis yaitu aspek pengetahuan atau pemahaman mengenai fungsi penting dari mahkluk hidup, kepekaan yang baik terhadap lingkungan, faktor kebiasaan dan kesadaran diri siswa, pertemanan atau pergaulan, adanya peran serta bimbingan dari orang tua dan guru tentang menjaga kesehatan lingkungan.

Pengetahuan dan pemahaman siswa tentang kesehatan lingkungan dapat siswa peroleh melalui pendidikan formal dan informal (Pradono, 2014). Terdapat hubungan yang signifikan antara pengetahuan lingkungan hidup dengan sikap menjaga kelestarian lingkungan (Azhar, 2015) yaitu semakin tinggi nilai pengetahuan lingkungan hidup maka akan semakin tinggi juga nilai sikap menjaga kelestarian lingkungan begitupun sebaliknya. Penelitian yang dilakukan oleh Istiana (2014) juga membuktikan bahwa aspek pengetahuan tentang pencemaran lingkungan mempengaruhi perilaku mahasiswa dalam mencegah bahaya pemanasan global. Aspek pengetahuan dan pemahaman mengenai fungsi penting dari makhluk hidup yang ada disekitar siswa akan mempengaruhi sensitivitas siswa terhadap kesehatan lingkungan dan siswa akan mengerti dampak (timbal balik) yang ditimbulkan oleh lingkungan yang tercemar dan tidak sehat (Darmawan, 2010). Tinggi rendahnya pengetahuan siswa dapat mempengaruhi sikap juga perilakunya. $\mathrm{Hal}$ ini sejalan dengan pernyataan dari Ginting (2016) bahwa pengetahuan yang baik akan berdampak pada sikap perilaku manusia yang baik pula.

Manusia yang memiliki kepekaan dan perilaku yang baik terhadap lingkungan dapat memilih simbiosis mana yang akan berpengaruh pada kesehatan lingkungan, 
serta manusia merupakan makhluk yang dapat berkompetisi dengan baik dalam lingkungan dibandingkan makhluk hidup lainnya. Manusia memiliki pengaruh yang penting dalam keberlangsungan ekosistem di tempat manusia itu berada, tindakantindakan yang diambil oleh manusia dalam memanfaatkan lingkungan akan berpengaruh bagi lingkungan dan diri manusia itu sendiri (Notoatmodjo, 2011). Hal ini sejalan dengan penelitian Soeharto (2004) yang mengatakan bahwa hubungan timbal balik manusia dengan alam sangat ditentukan oleh kemampuan manusia dan alam sesuai karakternya masing-masing. Keduanya memerlukan hubungan timbal balik secara berkelanjutan. Melalui pengelolaan lingkungan hidup secara bijaksana selain dapat menyelamatkan dan melestarikan lingkungan hidup, juga dapat menjamin kebutuhan dan kemakmuran umat manusia itu sendiri. Oleh karenanya disadari atau tidak, keseimbangan dalam lingkungan kehidupan manusia dan lingkungan alam dapat terganggu karena ulah manusia itu sendiri.

Kesadaran diri dan kebiasaan siswa juga mempengaruhi partisipasi siswa dalam menjaga kesehatan lingkungan. Guru memberikan pengetahuan tentang kesehatan lingkungan melalui pembelajaran IPA dan PLH di kelas VII dan VIII bersertadengan kegiatan-kegiatannya. Guru pun sudah membiasakan siswa untuk terbiasa dalam menjaga kesehatan lingkungan dan guru pun berharap agar siswa melakukan hal yang sudah dibiasakan tersebut untuk dilakukan juga pada lingkungan tempat tingal siswa. Faktor kesadaran diri siswa pun menjadi pengaruh penting lainnya dalam partisipasi dan perilaku siswa dalam menjaga lingkungan. Seperti yang dikatakan oleh Malikah (2013), bahwa kesadaran diri merupakan perwujudan dari jati diri seseorang yang dapat berpengaruh pada perilaku yang ia miliki.

Pertemanan atau pergaulan dapat juga mempengaruhi perilaku seseorang. Pergaulan tersebut dapat membawa siswa lain kedalam hal positif dan juga hal negatif. Hal positif yang terjadi dalam pertemanan salah satunya adalah partisipasi dalam menjaga kesehatan lingkungan. Sedangkan, pergaulan yang bersifat negatif salah satuya dapat mempengaruhi teman sekelompoknya engan ikut serta dalam berpartisipasi menjaga lingkungan bahkan acuh terhadap lingkungan. Hal ini sejalan dengan penelitian Septiyuni (2014) yang menyatakan kelompok teman sebaya sebagai lingkungan sosial bagi remaja (siswa) mempunyai peranan penting bagi perkembangan pribadinya.

Faktor yang terakhir adalah bimbingan atau peran dari orang tua dan guru. Bimbingan orang tua sangatlah penting karena orang tua adalah pembangun pondasi atau karakter siswa. Jika orang tua siswa tidak mendidik anaknya dalam menjaga kesehatan lingkungan maka siswa akan merasa bahwa menjaga kesehatan lingkungan tidaklah sangat penting. Hal ini sejalan dengan penelitian Surarti (2016) yang menyatakan bahwa perilaku orang tua terhadap pemeliharaan kesehatan sangat berpengaruh terhadap sikap dan perilaku anaknya serta peran orang tua dan guru sangat menetukan dalam melakukan perubahan sikap dan perilaku dalam memelihara kesehatan. Selanjutnya, peran guru di sekolah juga tidak kalah penting, guru bertugas memberikan stimulus terhadap siswa melalui pengetahuan, pemahaman serta praktik secara langsung dalam menjaga kesehatan lingkungan (Husin, 2012). Peran guru dan sekolah dalam membiasakan siswanya untuk belajar secara langsung dengan lingkungan, 
metode diskusi, praktikum, demonstrasi, dan permainan peran yang mengangkat isuisu lingkungan berdampak pada pembentukan karakter peduli lingkungan siswa (Caddafie, 2017).

\section{KESIMPULAN}

Berdasarkan hasil penelitian dapat disimpulkan bahwa terdapat hubungan antara variabel kecerdasan naturalis dengan partisipasi siswa dalam menjaga kesehatan lingkungan di SMP Negeri Se-Kecamatan Bogor Selatan. Hal ini menunjukkan terdapat pengaruh positif antara kecerdasan naturalis terhadap partisipasi siswa dalam menjaga kesehatan lingkungan. Hasil penelitian kualitatif menunjukan bahwa selain variabel kecerdasan naturalis yang berpengaruh terhadap partisipasi siswa dalam menjaga kesehatan lingkungan, terdapat pula variabel lain yang berpengaruh seperti faktor pengetahuan atau pemahaman siswa mengenai fungsi penting dari mahkluk hidup, kepekaan yang baik terhadap lingkungan, faktor kebiasaan dan kesadaran diri siswa, pertemanan atau pergaulan, dan adanya peran seta bimbingan dari orang tua dan guru tentang menjaga kesehatan lingkungan. Untuk itu lingkungan keluarga dan sekolah diharapkan membiasakan diri untuk memberi pendidikan sejak dini mengenai kesehatan lingkungan serta menyampaikan informasi secara menyeluruh bagaimana menjaga kesehatan lingkungan dan fungsi lingkungan pada siswa.

\section{DAFTAR PUSTAKA}

Anna, C. (2016). Hubungan Antara Kecerdasan Naturalis Dengan Sikap Peduli Lingkungan Siswa Kela III Sekolah Dasar Negeri SeKecamatan Gondokusuma Yogyakarta. (Skripsi). Fakultas Ilmu Pendidikan Uiversitas Negeri Yogjakarta.
Armstrong, T. (2009). Multiple Intelligence In The Classroom (3rd Edition). ASCD Member Book: USA.

Azhar, M. (2015). Hubungan pengetahuan dan etika lingkungan dengan sikap dan perilaku menjaga kelestarian lingkungan. Jurnal Ilmu Lingkungan, 13 (1): 36-41.

Baguma. (2017). Public health safety and environment in inadequate hospital and healthcare settings: a review. Public Health, 144: 23-31.

Can, C, Yafeiliua, Faber, M.D.(2017) Healthy urban living: Residential environment and health of older adults in Shanghai. Health \& Place, 47: 80-89.

Caddafie, S. U., Martuti, N. K. T., \& Rudyatmi, E. (2017). The Impact of Adiwiyata Program On Environmental Caring Character. Journal of Biology Education, 6(3), 350-356.

Chandra, B. (2006). Pengantar Kesehatan Lingkungan. EGC: Jakarta.

Darmawan, B. (2010). Hubungan Pengetahuan, Sikap, Perilaku dan Peran Serta Dengan Kesadaran Lingkungan. Prosiding Seminar Antrabangsa Ke-4 Ekologi, Habitat Manusia \& Perubahan Persekitaran di Alam Melayu. Universitas Riau.

Escobar, N., Ivanova, M., Buneo. (2018). The International Chemicals Regime: Protecting Health and the Environment. Green Chemistry An Inclusive Approach: 999-1023.

Fox, J. N., Alldred, P. (2016). Sociology, environment and health: a materialist approach. Public Health, 141: 287-293.

Gardner, H. (2009). Intelligence Reframed: Multiple Intelligence for 21 th Century (2nd Edition). Basic Books: New York.

Ginting, R. K., Ni, W. E. (2016). Pengaruh pengetahuan lingkungan terhadap niat membeli peoduk hijau pada merek "attack" dengan kepedulian lingkungan dengan variabel mediasi. E-journal mahasiswa, 5: 2223-2249.

Husin, A. (2012). Pengaruh metode pembelajaran dan kecerdasan naturalis terhadap pengetahuan siswa tentang konsep ekosistem.Jurnal Pendidikan Lingkungan dan pembangunan berkelanjutan, 13(2): 53-65. 
Istiana, R., Sudjono, H.S., Suhardi, E. (2014). Hubungan Antara Pengetahuan Pencemaran dan Etika Lingkungan dengan Perilaku Mahasiswa dalam Mencegah Pemanasan Global. Jurnal Ilmiah Pendidikan Pedagogia, 6 (1): $100-107$

Juniarti, Y. (2015). Peningkatan Kecerdasan Naturalis Melalui Metode Kunjungan Lapangan (Field Trip). Jurnal Pendidikan Usia Dini, 9(2): 267-284.

Malikah, M. (2013). Kesadaran Diri Proses Pembentukan Karakter Islam. Al-Ulum, 13(1): 129-150.

Nobuo, M. (2017). The healing balm of nature: Understanding and supporting the naturalist intelligence in individuals diagnosed with ASD: Comment on: "Implications of the idea of neurodiversity for understanding the origins of developmental disorders. Physics of Life Reviews, 20: 109-111

Notoatmodjo, S. (2011). Kesehatan Masyarakat Ilmu dan Seni. Rineka Cipta: Jakarta.

Peraturan Menteri Perdagangan Republik Indonesia No. 75 Tahun 2014 Tentang Pengadaan, Distribusi dan Pegawasan Bahan Berbahaya. Jakarta: Departemen Perdagangan

Pradono, J., Ning, S. (2014). Hubungan antara tingkat pendidikan, pengetahuan tentang kesehatan lingkungan, perilaku hidup sehat dengan status kesehatan. Buletin penelitian sistem kesehatan, 17: 89-95.

Rashidiyanti, P. A., Antara, P. A., \& Wiyasa, I. K. N. (2016). Peningkatan Kecerdasan Naturalis Melalui Metode Proyek Taman Kanak-Kanak (Penelitian Tindakan Kelas pada Anak Kelompok B3 Semester II di TK Kumara Jaya Sesetan Tahun Pelajaran 2015/2016). Jurnal Pendidikan Anak Usia Dini Undiksha, 4(1).

Septiyuni, D. A., Budimansyah, D., \& Wilodati, W. (2015). Pengaruh Kelompok Teman Sebaya (Peer Group) Terhadap Perilaku Bullying Siswa Di Sekolah. Jurnal Sosietas, 5(1).

Soeharto, B. (2004). Hubungan Timbal Balik antara Manusia dan Alam. Mimbar: Jurnal Sosial dan Pembangunan, 20(1): 26-34.

Sugiyono.(2016). Metode Penelitian Kuantitaif, Kualitatif dan Kombinasi (Mixed Method). Alphabeta: Bandung.

Sujiono, Y. N. (2009). Konsep Dasar Pendidikan Anak Usia Dini. PT Indeks: Jakarta

Suratri, L., Ayu, M., Sintawati, F. X., \& Andayasari, L. (2016). Pengetahuan, Sikap, dan Perilaku Orang Tua Tentang Kesehatan Gigi dan Mulut pada Anak Usia Taman Kanak-kanak di Provinsi Daerah Istimewa Yogyakarta dan Provinsi Banten Tahun 2014. Media Penelitian dan Pengembangan Kesehatan, 26(2): 119-126.

Yaumi, M. (2012). Pembelajaran Berbasis Multiple Intelegences. Dian Rakyat: Jakarta.

Yossinia, Rianto. S, Setriani. L. (2017). Kepedulian Siswa dalam Lingkungan Sebagai Outcome Program Adiwiyata Di SMAN 14 Padang. (Skripsi yang tidak dipublikasikan). STKIP PGRI Sumatera Barat. 